\title{
Group-Based Imputation and the International Criminal Law Discourse. Individuals and Associations as International Criminal Wrongdoers"
}

\author{
Charis Papacharalambous \\ Law Department, University of Cyprus, Nicosia, Cyprus \\ Email: papacha@ucy.ac.cy
}

Received July 24 ${ }^{\text {th }}, 2013$; revised August $26^{\text {th }}, 2013$; accepted September $23^{\text {rd }}, 2013$

\begin{abstract}
Copyright (C) 2013 Charis Papacharalambous. This is an open access article distributed under the Creative Commons Attribution License, which permits unrestricted use, distribution, and reproduction in any medium, provided the original work is properly cited.
\end{abstract}

\begin{abstract}
Collective agency is resurfacing within International Criminal Law (ICL) discourse; its genealogical traces can be found in socio-legal contexts like in systemic theories of liability, victimization-centered approaches and criminal policy models transforming traditional criminal law provisions into "combat norms". At the intersection between moral theories and law discourse, one can also trace as similar traits the discussions on the relations between corporations' and purely collective patterns of imputation, whereby selflessness is the main normative characteristic of the wrongdoer. At the level of criminal law, theorizing collective guilt can be made thematic through the methodological turn towards collectivism, the promotion of an aggregate knowledge model as appropriate liability form and the normative orientation towards the criterion of concerted action as individually imputable collective wrong. The qualified forms of co-perpetration within ICL discourse (like the "Joint Criminal Enterprise", the "Organized Structures of Power" or the "Joint Control of Crime") are then considered as slippery and ethnocentric hermeneutic tools for translating collective imputation into legal linguistics. Thereby recent developments in the jurisdiction of the International Criminal Court as well as in this of the newer internationalized courts are accordingly analyzed.
\end{abstract}

Keywords: International Criminal Law; Collective Guilt; Collective Agents; Co-Perpetration

\section{Introduction}

Collective agency is gaining ground since the end of last century in the framework of criminal law discourse. International Criminal Law (henceforth: ICL) seems very prone to following these developments. Before coming to terms with the spirit of the developments inherent in the ICL doctrine, taken as an autonomous epistemic field itself, I first refer back to the wider and more fundamental discursive environment; out of this can then emerge the contours of a type of genealogy of an ICL-related collective agency.

\section{Socio-Legal Background Theorizing}

We can trace the modern origins of collective agency in a field I would like to name "Socio-legal" i.e. where doctrinal solipsism is immersed in the Societal and emerges out of it in an altogether hybrid but at the same time productive form. I would mention three instances in this field:

\footnotetext{
*Enlarged and further elaborated version of a paper presented at the "Summit on Critical Approaches to International Criminal Law" at the University of Liverpool and under its auspices on 7.12.2012. I would like to thank the participants of the Conference for their remarks and suggestions. Special thanks to my friend and colleague Thomas Skouteris, Associate professor at the Law Dept. of the American University in Cairo for his invitation to the Conference and the fruitful discussions on the subject. I am also grateful to my then assistant researcher Ms. Natassa Aplikiotou for having gathered and duly classified a big amount of recent ICL Court Judgments.
}

1) Systemic theories of liability: especially concerning criminal law, discussions turn from classical personal culpability towards failures or wrongs in accomplishing social "roles". Thereby penalization figures as counterfactually securing societal normative expectations (e.g.: Jakobs, 1997, passim). Systemic theory in criminal law is one of many reactions against the traditional ideal type of the person to be criminally imputed as long as it is a socially "unencumbered autonomous monad", a conception already exposed to sharp critique also from a "critical-realist" standpoint (Norrie, 2000, passim). Systemic theory can be thus presented as the culmination of normativization in matters of imputing or blaming judgments.

2) Emphasizing victimization in new criminal law contexts, like organized crime, money laundering or terrorism. The borderline between personal guilt and guilt by association is blurred through this expansion of victimization; on the other hand this trend turns to be productive in fields like human trafficking in the sense that it is revealed as a "state crime" insofar as the state tolerates or under-reacts and thus indirectly contributes to it through omission.

3) Criminal policy models: where no normal criminals are to be punished but rather societal systems to be dealt with, the deviants become enemies, and insofar non-persons, who are to be confronted through "combat norms" (e.g.: Jakobs, 2004, passim; Jakobs, 2006, passim; Papacharalambous, 2007, passim). This instance can be labeled as "securitization" trend in 
the field.

\section{Philosophy of Morals and Law Discourse}

This time I shall proceed the other way around, that is not in a "bottom-up" schema (from society to legal codes) but in a "top-down" one (that is from moral theory to law). The discussion here revolves around the question: Are there collective agents? According to a recent revival of the respective discussion, there are such agents, namely as culmination in a climax beginning with amorphous collections of individuals, followed by more or less unified groups, within which one can discern group agents if the collective activity is intentional, especially jointly so and based on binary attitudes (List \& Pettit, 2011: 31-41). These collective agents are epistemologically autonomous units, i.e. non-reducible to the minds and deeds of their individual members. They function thus as an in-between figure apart from either a mystifying "emergentism" according e.g. to the organicist paradigm or from an "eliminativist" stance, based on the tradition of economics and analytical philosophy, and holding group entities either as fictions (useful according to utilitarian criteria and suitable to the nominalist approach as to the nature of universals) or otherwise as mere non-sense (List \& Pettit, 2011: 73-78). Even so, group agents are, if their robustness should be guaranteed, powerful in the first place; they are powerful, that is, irrespective of whether they are illegal or not. This means that individuals can exert only a weak and indirect control wherever a group agent arises (List \& Pettit, 2011: 129-150). More than that: members of a group can deploy a positive "we"-identification form by extinguishing their literally individual preferences in favor of the group identity ("collective amour proper"). This is the point where the possibility of international crimes begins to take shape (List \& Pettit, 2011: 193-195,197). An illuminating example displays in this regard the Australian legislative attempt to establish corporations' criminal liability for their involvement in contexts of international crimes occasioned mainly by motives of economic profit (see respectively Kyriakakis, 2007, passim and especially at 823-826). From the standpoint of "normative individualism" the aforementioned are reasons why, notwithstanding the recognition of group agents, the latter should not be given equal standing as well as why they have to be especially checked (List \& Pettit, 2011: 174-185).

Now, according to the above, the responsibility is corporate but still not collective. The latter may be intelligible though, wherever larger-looser groupings (religious congregations, nations, neighborhoods) omit to respect the law by at least allowing a group agent to become a spokesbody for themselves. That the latter exerts a dictatorial power over the social whole is a result they have or may have foreseen and accepted, at least insofar as one should hold that even if identity precedes rationality this identity should nevertheless remain individual without exceptions because only so can the collective deed be personally imputed. Punitively reacting against the grouping is coherent at least from the viewpoint of a "developmental regulation" of its behavior (List \& Pettit, 2011: 158-169,198-199). This means that the reaction should serve the purpose of not allowing the deed to happen again, in criminal law terminology: it should occur for reasons of general prevention (positive or negative). A crucial question as to this, which cannot be handled here in details, is whether ascription of guilt precedes the sanction or the latter perhaps over-determines the guilt. Ac- cording to the answer to this question the legitimization of the whole functional-systemic understanding of criminal law may stand or fall (cf. indicatively the critique on "normativist fallacy" of criminal law functionalism expressed by Schünemann, 1984: 58-60).

These new insights in group action have pervaded not only ICL but traditional complicity doctrine as well by making mens rea requirements "thinner". By transforming the mental element into a rather functional parameter, modern criminal law dispatches the accomplice's liability from the principal's. This is the case at least insofar as the volitional part of the former's mental element is not required in order for his/her mens rea to be established (the case of the "alienated accomplice") and as the requirement of qualified intent of the accomplice regarding the aim of the principal is also about to be abandoned letting recklessness suffice (the case of the "knowing but indifferent facilitator" $)$. In this framework accomplice liability tends to become more inchoate than in the past (cf. the partly critical approach of Kutz, 2011: 161-165).

On the other hand we have to be aware of the fact that the acknowledgment of autonomous collective agents which can be morally held blameworthy exclusively on a collective basis, may, instead of increasing, as it would seem at first glance, let penal austerity towards collective wrongdoing rather decrease, because collective guilt is considered as non-distributive (Isaacs, 2011: 23-93). In the course of such a reasoning even membership responsibility is not collective; further, individuals implicated in collective organizations are accountable not for the collective act but individually as having acted in a collective frame, even if they are leaders; this is the more so, i.e. the basis of moral imputation remains the more individual, the more the involvement refers rather to goal-oriented groups than to organizations more or less structured (Isaacs, 2011: 97-129). The link to collectivities becomes, the argument goes, weaker in mere collective contexts or cultural patterns, where wrong is socially ignored as long as it is widely tolerated; there, one can speak only of individually based moral responsibility, addressable through education and demands for social change (Isaacs, 2011: 130-174). Blameworthy contributions to serious forms of delinquency seem though to contradict this lessening of "jus puniendi": is the client of sexual services merely morally-individually responsible as acting in an immoral social pattern? Isn't he to be considered as part of the trafficking scene? As the argument goes, collectively indicated moral responsibility cannot be translated in criminal participation at the organized crime of trafficking. Is the Swedish legislator then ill-reacting by punishing such conduct?

At a fundamental level of moral analysis, collective guilt cannot be denied on the grounds of relativism engendered by the so called "moral luck" problem. Whatever reasons can be invoked against the detachment of condemnation even from contingencies deemed as crucial, no one harmed can be denied the expectation of receiving an apology for the harm suffered from the part of the harming community member (beyond and before any specific form of judgment): guilt for belonging to the evil collective is pre-reflexive (Cooper, 2001: 211-214). The collective guilt issue can principally be analytically also sepa-

\footnotetext{
${ }^{1}$ Whereby also the problematic of "neutral acts" and socially congruent roles reemerges: e.g., the gun seller or the professionals in the organized crime or money laundering scene tend to become accomplices due to their mere cognizance or even suspicion of their clients' ultimate criminal aims, although they may exert their roles legally.
} 
rated from the question about the collective nature of the protected interest: even if the variety of natural species cannot be proposed as such interest, even if under "group interests" cannot be assumed but interests which are fundamental but simultaneously still personal, there is sense in discerning collective forms of liability from individual ones, for they qualitatively increase the wrongfulness of the misdeeds (Zanetti, 2010, passim).

Support for broadening the scope of liable persons comes also from utilization of ethical philosophy in an unmediated manner, even if this is not tantamount to holding that the guilt is primarily or basically collective. An example is the interpretation of Australian case-law on torts on the grounds of the Levinasian ethics: "proximity" may thus become the conceptual lever driving to an utmost extension of liability (Manderson, 2006, passim). Whether this can apply also in criminal matters, is though something very much contentious.

\section{Criminal Law Theory}

"Plural subjects" are in moral theory conceivable but this alone entails still nothing concerning the legal liability of their members, even when they are temporally concurrent to the misdeeds of the group (Gilbert, 2010, passim and especially 55-64). Worse than that: collective agency may imply collective exculpation, which legitimizes impunity if it excludes individuation of the process of imputing criminal liability, e.g. by granting excuse of lethal acts for soldiers participating in a war of aggression (Rodin, 2010, passim and especially 230-238). To translate as criminal a moral collective responsibility one has to accept a "methodological collectivism" even if one is not ready to accept an "ontological" one: then, one is not excluding criminal liability of collectives, nor is reducing it to individual liability, but is imputing collective liability individually and if needed preemptively (Gerber, 2010, passim and especially 68-69,72-73,79-85,89-91; on the non-ontology of group agents, see also Gilbert, 2001: 229-231). "Methodological individualism" seems, at any rate, pre-modern and normatively feeble, ignoring that even individual imputation remains socially constructed: insistence on it may illegitimately exonerate and "naturalize" responsibility (Korenjak, Ungericht, \& Raith, 2010, passim). Compatible with this approach is e.g. the focus on the violation of "integrity" standards viewed under their social, moral and epistemic aspect for imputing collective moral responsibility for omissions; this is deemed to avoid distributive models of individually ascribing collective responsibility and to integrate relational parameters (modes and forms of complicity) into the concept (Schweikard, 2010, passim and especially 116-119,129,132-133).

Holding that the collective guilt thesis is an absurdity, is not that obvious any longer; it is to be henceforth considered as an object of legal history rather (cf. e.g. Rothenpieler 1982, passim, especially 278 et seq.). However, the declaration of Nazi organizations as criminal still did not exclude but on the contrary required the personal culpability of the members; membership alone did not suffice; insofar the case was one of an expanded individual liability (Vest, 2010: 329-330).

Purely collective is the criminal liability when the association bears it as such. Opposite to this, the association's liability is not original but derivative, when it is imputed to it through the personal liability of another, who may be either the low ranking employee whose conduct is vicariously transferred to higher ranking directing persons (this is the US "respondeat superior" model) or directly the mind of the corporation irrespective of the corporation's "hands" conduct: this is the British "identification doctrine", meaning that the corporation is identified at the manager's person. Different from all these forms would be a purely strict liability model: it would be oriented at the endangerment displayed by the association and proceed to conviction without serious evidential problems. The normative problem there would be how to harmonize international criminal law, i.e. the arch-crimes, to a liability form dispensing totally with the mens rea requirement. Can we have collective wrong without collective guilt? Further: what kind of evil would this be, if we still need that notion? Is collective entity to be dealt with as "natural" evil, something like a storm or a flood? Closer to international criminal blameworthiness seems then only the "aggregate knowledge model" as to corporation liability: the liability is not derivative (the entity is culpable) and also not strict (the natural persons are jointly reckless). There is always a concerted action with regard to international crimes, implied e.g. in the contextual elements of the crimes against humanity or of genocide, irrespective of whether they are objective or subjective in nature (Vest, 2010: 334-342). Macro-criminality transforms indeed through the organized form of planning and conduct a simple murder to crime against humanity. In this sense "personal wrongdoing" does not any more mean "individual wrongdoing" but rather entity's culpability which renders the "societas delinquere non potest"principle all the more obsolete (see on this Militello, 2010, 523-530; see also from the newest ICL jurisdictions e.g.: East Timor-Special Panel for Serious Crimes, Prosecutor v. Agustinho Atolan alias "Quelo Mauno", at page $5^{2}$ ). At the level of national jurisdictions it is true that the British 2007 Corporate Homicide Act features as a good example of "corporate crime" in displaying dimensions of holistic-aggregative responsibility of sorts by focusing on management as common activity pattern adding particular breaches of tort law-based duties of care, grossly perpetrated (see e.g. Herring, 2008: 758-759,762-764).

On the other hand, "corporate killings" are considered by many as rather "regulatory offences". Even those affirming this form of homicide and thus proposing its separate provision as special homicide offence do stress the distinction to mens reabased killings, intentional, reckless or even negligent ones (Clarkson, 2000: 151-153). But, again: the element of "concert" finds its limit where a de-personalization of guilt begins, where what is imputed is a "natural" or "structural" evil. There is no "concert" without personal contribution. Even if international crimes are committed by ordinary people in extraordinary times (whereas normally a crime is held as committed by "extraordinary" people acting in "ordinary" times), one is not to blame for the times but for the act done. Insofar the individualist (and as to international relations cosmopolitan-liberal) assumption that the international criminal is an evildoer, worthy

\footnotetext{
${ }^{2}$ As the text at the end of this page goes: "A single act of murder, if it is a portion of a wider plan of aggression against civilian population, is qualified a crime against humanity and deserves a more severe treatment because, amongst other reasons, the participants to the plan, granting themselves, explicitly or not, mutual support and trust and shelter, seal a bargain which strengthen their capacity to strike and to gain impunity. In these conditions the single individual looses or weakens his sense of responsibility of self-accountability, becoming a part of an organization whose goals transcend the wills and the strengths of the members. And in the crime outlined in the charge these features occur, since the gathering and the planning of killings, wreckage and disruption on an unidentified and indistinct mass of potential victims is the setting in which the murder is located" (emphasis added).
} 
to be blamed as "moral monster" remains still valid, epistemologically at least if not ontologically, but of course at the backstage somehow within legal theorizing on international crimes, namely as a heuristic label of concretizing collective evil (cf. partly differently Ainley, 2008, passim; on the difference between evil and risk as prohibiting strict liability in ICL, see also Papacharalambous, 2011: 99).

The concrete appearance of collective evil may be thus interpreted as de-personalization of the agential self of the criminal, his/her chosen selflessness, so that evil may be unleashed without individual competence for the sake of getting (mainly and primarily sadistic) satisfaction as a sub-human. Insofar collective evil is not "taking place" but is done, i.e. the decision to become non-agential remains a fully-fledged agential choice (so rightly Vetlesen, 2008: 66-67,71,82-84).

What seems to be out of question in case of a collective guilt approach (even if it is not conceived of as pure but rather as based on a "shared intentions" model) is that there is no place for a separate accomplice's mens rea: whoever knows of and approves the context is held as willing the result. The co-perpetrator needs e.g. not share the ulterior genocidal intent, it suffices if he/she knows that the planners have it (May, 2010: 350-364,370). Despite the fact that lesser forms of complicity may attenuate the sanction in the sentencing stage, they can principally nonetheless be also linked to the crime if only recklessness or grave negligence is established (May, 2010: 366-367).

An issue quite different (and for itself enormously demanding) is, on the other hand, this concerning the nature of a collective-based criminal sanction.

Collective guilt should from the very start be discerned from any retaliatory imposition of pain on groups deemed as abstractly hostile. No notion of criminal responsibility is thereby required, not even in the form of "joint venture" of any kind. In such cases we are facing the crime of "collective punishment", already envisaged as mainly a war crime, laid down as such in various international legal texts, as for example the Statutes of ICTR, ICC or the Special Court for Sierra Leone [henceforth: SCSL] (see indicatively Werle, 2009: 404-405).

What is, though, further at stake is especially whether such sanction should be something more than safety measures or "naming and shaming" procedures. Here is the materialization of criminal liability of states squarely placed (Vest, 2010: 342325 ). If military action against a delinquent state can be considered as such sanction, one is almost continually confronted with the possibility of blatantly accepting rough distribution of collective guilt to individuals, at least to some degree (Erskine, 2010: 254-271). An analogous context is the following: What about actions not overtly military and based on international law? How is for example the internationally "legal" condemnation to death of hundreds of Iraqi children occasioned by the UN embargo resolutions in the 90' ties to be judged? May the $U N$ be conceivable as criminal "world"-state? (See, on the terrifying effects of the Iraqi embargo and its tremendous normative questions it poses, Veitch, 2007: 12-19).

\section{ICL Discourse; The Patterns}

In the framework of ICL the collectivization of criminal guilt has been partly digested, that is lower than the level of state or other multi-state international agents but almost entirely at the level of other group-based actions. Mainly criminal participation and especially co-perpetration have become respectively thematic. As up to now we can discern 4 forms of qualified co-perpetration in ICL (Olásolo, 2010, passim, especially 153 et seq.; Van Sliedregt, 2012: 131-147, Papacharalambous, 2011, 91-94):

1) The "Joint Criminal Enterprise" ("JCE") model, in the framework of which the defendant becomes primary perpetrator according to the unitary model. There has been a clear ICTY and ICTR jurisdiction in favor of JCE after 2003 ICTY Appeals Judgment on JCE (Ojdanić). In sum, collective wrong notions span from members' responsibility as of them having being cogs in the machinery (JCE II type/"institutionalized" responsibility form) up to members' responsibility as of the fact that they should have known the possibility of the excesses of others (JCE III type/“collateral" responsibility form) and whereby the volitional constituent of intent turns almost redundant, recklessness and negligence are blurred, actus reus becomes "thin" as long as it is mainly subjectively based, and guilt is reduced to strict liability despite the grievous nature of international crimes which makes them candidates par excellence for a mens rea requirement (Werle, 2009: 172-176). After the Brđanin Appeals Judgment became clear that principals needed not to be part of the JCE, strictly speaking, that JCE were applicable in all cases irrespective to how "large" they might be, and that no specific agreement with the executioners was required; in this context the guarantee that JCE remains distinct from an "openended", association-based guilt pattern or that the contribution of the defendant had to be "significant", even if not substantial (!), can hardly hold as legally lucid solutions (cf. Gaynor \& Goy, 2007: 1179-1182). So, it was not surprising that also financing of international crimes could be regarded as one more form of JCE (Piacente, 2004, passim, and at 453-454).

Questions arising out of all this may be such like the following: Is this not some kind of revival of the "Jamashita" syndrome, extending now participation beyond the confinements of "command responsibility"? More generally: does not a normative model overturn here fully any notion of naturalistic "commission"? As a last doctrinal resort may perhaps serve here the civil law of "actio libera in causa" (a.l. i. c.), of which the common law equivalent is the so called "Dutch courage cases model". JCE, especially this of the $3^{\text {rd }}$ form, can then be conceived of as a sophisticated form of the "versari in re illicita" principle, introducing an anticipative temporality as to culpability, a guilt in a "pluperfect tense" in the course of a clearly antinaturalistic, normative model of imputation for collective crimes (see especially on this: Papacharalambous, 2011: 95101; Rodin, 2010: $226^{3}$ ).

More or less recently issued ICL judgments either:

a) recur to participation (aiding, abetting, planning etc.) underlining the frequent appearance of evidential hurdles in accepting collective guilt forms of liability (SCSL, Prosecutor $v$. Ch. Taylor, at pars. $142-4,145$ et seq. [168], 169 et seq. [177]; SCSL, Prosecutor v. Fofana and Kondewa, Appeals Chamber, for example at pars. 112, 154 and at paragraph 31 of the partly dissenting opinion of Justice R. Winter; East Timor-Special Panel for Serious Crimes, Prosecutor v. Pereira, at pp. 19-20, against which Judge Phillip Rapoza expressed his dissenting opinion in favor of JCE by lowering the requirements as to the explicit character of the common agreement and to the proof of qualified intent as well: ibid, Separate Opinion of Judge Phillip Rapoza, at pars. 25, 27, 30) or

${ }^{3}$ The link can thus be made with the "chosen selflessness" thesis, referred to in the previous subchapter. 
b) sporadically set JCE closer to traditional complicity (e.g. dissenting opinion of Judge B. M. Itoe in: SCSL, Prosecutor v. Fofana and Kondewa, Trial Chamber I, at pars. 73-75,132; East Timor-Special Panel for Serious Crimes, Prosecutor v. Jose Cardoso, at pars. 367-376 and at 460-462: accessorial liability and co-perpetration of a militia commander, as to the rest a member of a JCE, for the rape of a victim committed by others) or

c) contrary to the above remain with or return in a full-blown form of acceptance of JCE (SCSL, Prosecutor v. Sesay, Kallon \& Gbao, Trial Chamber I, passim, whereby, regarding especially the $3^{\text {rd }}$ accused, JCE was assumed on the basis of his ideological contribution to the collective purpose, an argument, which caused a strong dissenting opinion of Justice Pierre Boutet, ibid, at pp. 689-694, among others concluding that through this expansive interpretation of JCE the defendant, apart from his guilt as to some aiding and abetting, has not adequately received notice of the JCE-charges against him; this last argument found resonance at the Appellate Court in that "ideology" was not accepted as sufficient in itself; however, the Court affirmed JCE as to the rest, i.e. concerning other constituents of it or the other 2 defendants, with the exception of one crime from JCE as to all three: SCSL, Prosecutor v. Sesay, Kallon \& Gbao, Appeals Chamber, passim and at pars. 173-182, 304-305,455 ${ }^{4}$; Extraordinary Chambers in the Courts of Cambodia [henceforth: ECCC], Prosecutor v. Kaing Guek Eav alias "Duch", pars. 487-516, where the Court finds that a JCE II form was to be imputed to the accused ${ }^{5}$, whereas also his accessorial liability has been confirmed (pars. 532-537); East Timor-Special Panel for Serious Crimes, Deputy Prosecutor General v. Barros \& Mendonca, pars. 123-1436; East TimorSpecial Panel for Serious Crimes, Prosecutor v. Salvador Soares, pars. 187-189). Acceptance of JCE emerges implicitly also in cases of recourse to traditional co-perpetration, whereby liability for crimes committed by others is imputed to a member of a group, who beyond being simply present on the spot takes actively part in the atrocity (East Timor-Special Panel for Serious Crimes, Prosecutor v. Martins \& Goncalves, at p. $14^{7}$ ). And, of course, naturalistically conceivable contributions do not do more than merely stress the JCE-like responsibility. Main recent precedent on this constellation is a case of exerting during a siege maneuver a crucial role (by holding a gun) in enhancing the criminal results, which has been considered as part of a conduct subsumed under article 14.3(d) of UNTAET

${ }^{4} \mathrm{Cf}$. though ibid. the devastating critique to the majority's judgment exerted by Justice Shireen Avis Fisher in pars. 1-46 of her dissenting opinion as to the $3^{\text {rd }}$ accused: the judgment is accused of circularity, conflation of different JCE modes' mens rea and improper construal of the Trial Chamber judgment by assuming existence of facts the latter did not really find.

${ }^{5}$ This was assumed contrary to the initial exclusion of the JCE mode of liability by the Pre-Trial Chamber in that case. The Trial Chamber judged based on Internal Rule 98(2) that the inclusion it now affirms was a mere legal re-characterization of the same facts through an applicable liability form and insofar admissible as long as the fair trial rights of the accused were not violated.

${ }^{6}$ Whereby though it must be noted that the Court does not use explicitly the designation "JCE", instead referring to "joint enterprise", "common purposel enterprise" or even "common criminal enterprise", thus indirectly allowing for interpretations possibly favoring a linkage of the crucial liability mode to a more traditional co-perpetration.

${ }^{7}$ There, the following is respectively stated: "On these premises, the multiplicity of murders and other crimes [...] is merged in a unity, $w[h] e r e$ the identity of a single crime is lost and the participants bear the burden of the whole. In the end, it was a single, yet multifaceted, action and those who gave a contribution to it are responsible not for the single element that they directly committed but also for its entirety" (emphasis added).
Regulation 2000/15, which is identical to article 25(3)(d) ICCSt. (East Timor-Special Panel for Serious Crimes, Prosecutor v. Joseph Leki, at p. 8).

2) The "Joint Control of Crime" model ("JCC"), meaning co-commission or at least functional if not real-natural control over the crime; this is mainly the case with the leaders' liability, which fact does not preclude the possibility of participation in the technical sense (accessorial liability). In this sense, a preparatory act committed by the leader can make him/her primary perpetrator, whereas an encouragement from his/her part towards the executioners during the atrocity may still be a case of abetting. Primarily these are cases of horizontal co-operation among the wrongdoers (ICC, Lubanga, Decision on the Confirmation of Charges, pars. 342-367, and as to the actus reus of the accused: pars. 372,376,378-379,383,396-398; analogously: ICC, Prosecutor v. Lubanga, Trial Chamber, pars. 976-988,994, 997,999,1003-1006: joint perpetrator liability based on art. 25(3)(a) ICC-St. as to the actus reus, therefore qualified, "essential", contribution is required in comparison to accessories', "substantial", one; East Timor-Special Panel for Serious Crimes, Deputy Prosecutor General v. Metan, paragraph 14 in fine: "joint perpetration" based on article 14.3(a) of UNTAET Regulation 2000/15, which is identical to article 25(3)(a) ICC-St.; the same is also assumed in East Timor-Special Panel for Serious Crimes, Prosecutor v. Tilman, paragraph 47; Prosecutor v. Da Costa Nunes, pars. 62-63; Prosecutor v. João Sarmento, pars. 81-82, as well as, together with aiding and abetting concerning other victims, in Deputy Prosecutor General v. Francisco Pedro, pars. 11,14).

Through the "control-test" the traditional "but for-test" of the domestic criminal law is reemerging: crucial is that the crime to be jointly committed could be frustrated if someone withdraws himself from it; the flip side of this is that co-perpetrator can be only someone rendering an essential contribution to the crime. This means as to the mental element that mere foreseeability of an excess will not suffice; it also means that all participants should share the mens rea level required for the respective crime. All these peculiarities dissociate the JCC from the JCE model, i.e. the ICC jurisprudence from the one followed by the ad hoc Tribunals (Werle, 2009: 176-178; a summary general overview of art. 25 ICC-St. see also in Werle, 2007, passim). The ongoing acceptance of JCC is a symptom of a return to accessorial liability, even if only for the sake of differentiations in the judgments concerning sentencing (Werle und Burghardt, 2010: 850-853); besides, it is better serving the avoidance of vagueness in statutorily exactly describing the participatory actus reus (Militello, 2010: 526-527), without of course overcoming the tension in accomplices' liability between the need for restriction and its inherent trend to expansion, a feature only magnified in the case of ICL (Dubber, 2007: 1001).

3) The "Organized Structures of Power" model ("OSP"), meaning perpetration through another. This is the case of the Latin American juntas (e.g. Argentina) or of GDR-like incidents. Contrary to the $2^{\text {nd }}$ model this one presupposes a vertical hierarchical relationship between leader and executioner and the interchangeability of the executioners in a context where lawfulness is a conduct alternative with extremely low probability, it cannot namely be reasonably expected (see also Werle und Burghardt, 2010: $855-857$, but cf. at 856 as to the "lawlessness" criterion). The problem here is the trend of this model to assume perpetration through others who are not "innocent agents", as long as they normally still have the intent to 
act as primary perpetrators. ICC seems to affirm this assumption sliding over the respective doctrinal controversies (Werle und Burghardt, 2010: 853-854). One tries there to focus rather on the lessening of freedom in acting than on being legally responsible for the act, in order to legitimize perpetration through another despite the latter's liability and because of his/her submissiveness (Schlösser, 2004, passim).

4) The "Mixed" model issuing at a synthesis between JCC ка OSP: here we have an "indirect co-perpetration"/"coperpetratorship" of sorts. Condition is the leadership in the frame of structures without the OSP-characteristics, whereby the executioners have not taken part at the common planning and thus principally accessorial liability should hold. So, the leader may feature as instigator or abettor of the primary perpetrators, according to the circumstances. As to case law illustrating the mixed model one may indicatively refer to:

a) The ICTY Trial Chamber Judgment in re Stakić, whereby the defendant in common with 2 other leaders committed persecutions in Prijedor and the defendant exerted control as head of the local administration (mayor) organizing the military and militia activities, which "but for" his contribution would have not taken place; the defendant was not the direct head of these two collective entities, nevertheless (Prosecutor v. Milomir Stakic, Trial Chamber Judgment, pars. 431-442,468-498 ${ }^{8}$,

b) The ICC Arrest Warrant Decision in re Bemba Gombo. Here the defendant was indicted as co-perpetrator of war crimes during the Congolese civil war and has been charged with dolus eventualis as to his mens rea (Bemba Gombo, pars. 69-84),

c) The ICC Confirmation of Charges Decision in re Katanga and Ngudjolo Chui. There, the defendants organized the attack against civilians and controlled formally the paramilitary executing bands. The defendants have not taken part at the deeds; the bands disposed over a hierarchical structure, which has not reached the threshold of an OSP though (Katanga and Ngudjolo Chui, Part IV, Subchapters A and B) ${ }^{9}$.

d) The ICC Arrest Warrant in re Al Bashir. There, the defendant was Chief of Sudanese Military which allegedly committed international crimes against members of certain tribes in the Darfur region since 2003. The crimes were carried out upon decisions of several boards, such as the government, security agencies and militias (Al Bashir, passim and at page 7) ${ }^{10}$.

In the frame of this $4^{\text {th }}$ model one should discern between 1 ) cases of co-perpetration between indirect perpetrators for acts carried out through others separately subordinated to them; the acts committed by each group's members are imputed then to the leader of the other group. Here, point of departure remains the co-perpetration (but the agents are indirect ones) and 2) cases of indirect perpetration, committed co-operatively with others and carried out by other primary perpetrators acting as executioners (whereby, OSP-characteristics are especially stressed). Here, point of departure is indirect perpetration (but the indirect perpetrator is a collective) (Werle und Burghardt, 2010: 857-863).

Noteworthy seems though that intra-systematic criminal law differentiations deepening in the scope and variety of forms of collective liability is one thing whereas the "maximalism" of

${ }^{8}$ Whereas the Appeals Chamber returned afterwards again to JCE, the ICTY familiar mode of liability: cf. Prosecutor v. Milomir Stakić, Appeals Chamber Judgment, pars. 62-63,66-104; there "co-perpetratorship" is held as a legally errant construction without customary grounding.

${ }^{9}$ Meanwhile Ngudjolo Chui has been acquitted and released.

${ }^{10}$ On 12.7.2010 another Arrest Warrant followed with additional charges (on genocide). absorbing international into the criminal law is another (but cf. so Cassese, 2007: 881-887 as to the ICJ's 2007 Judgment on the Bosnia v. Serbia case). Therefore, it is not, for example, necessary to consider crime types like "complicity in genocide" as redundant forms of the participation doctrine of domestic criminal law: the international nature of genocide may be seen as conveying to "complicity in genocide" (as it has been laid down in art. 4 ICTY-St. and art. 2 ICTR-St.) a specific character different from the complicity doctrine and rather inherited from an international legal source, namely the 1948 Convention. Insofar, it would represent a provision of a special crime covering all possible forms of criminal "synergy" to genocide falling outside accessorial liability, whereas the participation doctrine represents a liability form, accessorial to any international crime and not a specific crime in itself (cf. so e.g. Eboe-Osuji 2005, passim, and at 67-81, among others also referring, for example, to the vicissitudes in identifying the nature of "participants" after the fact). The role of comparative studies becomes therefore all the more important as long as it seems that the future ICL will turn emphatically hybrid (see on this regard also Delmas-Marty, 2003, passim).

\section{Two Concluding Remarks}

Coming to the end of present analysis, let me point out two aspects of a more general concern. First, it can be maintained as a general trend, that there is an ongoing normativization of complicity inside a multitude of liability models (Van Sliedregt, 2012: 153-155). Even if the acceptance of JCE was unreflective, and the acceptance of the control theory through the ICC case law is "hagiographic", we can no more simply concentrate ourselves on the mens rea of the group members and then recur to only accessorial liability when intention cannot be assumed (as in such cases of the JCE-III where the defendant knows but doesn't intend). This is, though, Ohlin's thesis (Ohlin, 2012: 280-290). This thesis returns us back to the animus theories, invalidating the whole turn to analyzing collectivity as a renewed field of inquiry. It practically dissolves this turn into traditional mens rea based participation teachings, whereas the focal point should be primarily rather the structural modifications of the collective actus reus.

Second, both the $2^{\text {nd }}$ and the $3^{\text {rd }}$ model display tensions inherent in the theory on agent's domination upon the deed ("act dominion theory"; "Tatherrschaftslehre", as it has been admirably elaborated by Roxin), on which especially the control model has been based (its heuristic value more than its epistemological accuracy stresses Dubber, 2007: 981-984,1001). These tensions are due to the nature of the phenomenon of collective macro-criminality itself, which forces doctrine to elaborate hyper-normative exegetic models, to seek refuge in vagueness and tolerate lacks of comprehensiveness. Dominion theory may be thus forced, if it is applied beyond OSP-like cases, to further spiritualize "control", whereby the "remote principal" will only fictively "commit", becoming practically nothing more than a completely vicariously liable person (Van Sliedregt 2012: 81-88,165-170). Isn't this a "totalizing" effect produced by visiting global phenomena through a Eurocentric lens (cf. also the comments of Werle und Burghardt, 2010: 855)?

\section{REFERENCES}

Ainley, K. (2008). Individual agency and responsibility for atrocity. In R. Jeffery (ed.), Confronting evil in international relations. Ethical 


\section{PAPACHARALAMBOUS}

responses to problems of moral agency (pp. 37-60). Basingstoke, UK: Palgrave Macmillan.

Cassese, A. (2007). On the use of criminal law notions in determining state responsibility for genocide. Journal of International Criminal Justice, 5, 875-887. http://dx.doi.org/10.1093/jicj/mqm037

Clarkson, C. M. V. (2000). Context and culpability in involuntary manslaughter: Principle or instinct? In A. Ashworth, \& B. Mitchell (eds.), Rethinking English Homicide Law (pp. 133-165). Oxford New York: OUP. http://dx.doi.org/10.1093/acprof:oso/9780198299158.003.0006

Cooper, D. (2001). Collective responsibility, "Moral Luck", and reconciliation. In A. Jokić (ed.), War crimes and collective wrongdoing. A reader (pp. 205-215). Malden, Massachusetts (USA); Oxford (UK): Blackwell.

Delmas-Marty, M. (2003). The contribution of comparative law to a pluralist conception of international criminal law. Journal of International Criminal Justice, 1, 13-25.

http://dx.doi.org/10.1093/jicj/1.1.13

Dubber, M. D. (2007). Criminalizing complicity. Journal of International Criminal Justice, 5, 977-1001. http://dx.doi.org/10.1093/jicj/mqm038

Eboe-Osuji, C. (2005). "Complicity in Genocide" versus "Aiding and Abetting Genocide". Constuing the difference in the ICTR and ICTY statutes. Journal of International Criminal Justice, 3, 56-81. http://dx.doi.org/10.1093/jicj/3.1.56

Erskine, T. (2010). Krieg und korporative Verantwortung. Das Problem der Bestrafung "delinquenter" Staaten. In D. Gerber, \& V. Zanetti (eds.), Kollektive Verantwortung und internationale Beziehungen (pp. 239-271). Frankfurt: Suhrkamp.

Gaynor, F., \& Goy, B. (2007). Current developments at the Ad Hoc international criminal tribunals. Journal of International Criminal Justice, 5, 1175-1214. http://dx.doi.org/10.1093/jicj/mqm069

Gerber, D. (2010). Der Begriff der kollektiven Verantwortung: Ist individuelle Verantwortung das richige Modell für kollektive Verantwortung, In D. Gerber, \& V. Zanetti (eds.), Kollektive Verantwortung und internationale Beziehungen (pp. 66-93). Frankfurt: Suhrkamp.

Gilbert, M. (2001). Collective remorse. In: A. Jokić (ed.), War crimes and collective wrongdoing. A reader (pp. 216-235). Oxford (UK): Blackwell.

Gilbert, M. (2010). Wer ist zu verurteilen? Kollektive moralische Verantwortung und ihre Auswirkung auf Gruppenmitglieder. In: D. Gerber, \& V. Zanetti (eds.), Kollektive Verantwortung und internationale Beziehungen (pp. 31-65). Frankfurt: Suhrkamp.

Herring, J. (2008). Criminal law. text, cases, and materials. Oxford New York:: OUP.

Isaacs, T. (2011). Moral responsibility in collective contexts. Oxford New York:: OUP. http://dx.doi.org/10.1093/acprof:oso/9780199782963.001.0001

Jakobs, G. (1997). Norm, Person, Gesellschaft. Vorüberlegungen zu einer Rechtsphilosophie. (Berlin): Duncker \& Humblot.

Jakobs, G. (2004). Bürgerstrafrecht und Feindstrafrecht. Höchstrichterliche Rechtsprechung Strafrecht (HRRS), 3, 88-95.

Jakobs, G. (2006). Feindstrafrecht? Eine Untersuchung zu den Bedingungen von Rechtlichkeit. Höchstrichterliche Rechtsprechung Strafrecht (HRRS), 8-9, 289-297.

Korenjak, T., Ungericht, B., \& Raith, D. (2010). Unternehmen als Verantwortungsfähige Akteure. Ein Beitrag zur Zurechenbarkeit von Verantwortung in Zeiten der Globalisierung. In D. Gerber, \& V. Zanetti (eds.), Kollektive Verantwortung und internationale Beziehungen (pp. 137-159). Frankfurt: Suhrkamp.

Kutz, C. (2011). The philosophical foundations of complicity law. In J. Deigh, \& D. Dolinko (eds.), The Oxford handbook of philosophy of criminal law (pp. 145-167). Oxford New York: OUP. http://dx.doi.org/10.1093/oxfordhb/9780195314854.003.0006

Kyriakakis, J. (2007). Australian prosecution of corporations for international crimes. The potential of the commonwealth criminal code. Journal of International Criminal Justice, 5, 809-826. http://dx.doi.org/10.1093/jicj/mqm047

List, C., \& Pettit, P. (2011). Group agency. The possibility, design, and status of corporate agents. Oxford New York: OUP. http://dx.doi.org/10.1093/acprof:oso/9780199591565.001.0001
Manderson, D. (2006). Proximity, levinas, and the soul of law. Montreal \& Kingston, London: McGill-Queen's UP.

May, L. (2010). Kollektive und individuelle Absichten und das Verbrechen des Völkermords. In: D. Gerber, \& V. Zanetti (eds.), Kollektive Verantwortung und internationale Beziehungen (pp. 347-371). Frankfurt: Suhrkamp.

Militello, V. (2010). Internationale Verbrechen und Grundsätze des Strafrechts. In FS für M. Maiwald (pp. 519-538). Berlin: Duncker \& Humblot.

Norrie, A. (2000). Punishment, responsibility, and justice: A relational critique. Oxford New York: OUP. http://dx.doi.org/10.1093/acprof:oso/9780198259565.001.0001

Ohlin, J. D. (2012). Joint Intentions. In F. Tanguay-Renaud, \& J. Stribopoulos (eds.), Rethinking criminal law theory. New Canadian Perspectives in the Philosophy of Domestic, Transnational, and International Criminal Law (pp. 267-290). Oxford and Portland, Oregon: Hart.

Olásolo, H. (2010). The criminal responsibility of senior political and military leaders as principals to international crimes. Oxford and Portland, Oregon: Hart.

Papacharalambous, C. (2007). "The Penal Law of the Foe": Beyond Liberalism. Poinikos Logos, 3, 819-824.

Papacharalambous, C. (2011). Joint criminal enterprise: Towards a new concept of criminal participation? In P. Cserne, \& M. Könczöl (eds.), Legal and political theory in the post-national age (pp. 89-104). Frankfurt am Main, Berlin, Bern, Bruxelles, New York, Oxford, Wien: Peter Lang.

Piacente, N. (2004). Importance of the joint criminal enterprise doctrine for the ICTY prosecutorial policy. Journal of International Criminal Justice, 2, 446-454. http://dx.doi.org/10.1093/jicj/2.2.446

Rodin, D. (2010). Kollektive Entlastung im Krieg. In: D. Gerber, \& V. Zanetti (eds.), Kollektive Verantwortung und internationale Beziehungen (pp. 219-238). Frankfurt: Suhrkamp.

Rothenpieler, F. W. (1982). Der Gedanke einer Kollektivschuld in juristischer Sicht. Berlin: Duncker \& Humblot.

Schlösser, J. (2004). Soziale Tatherrschaft. Ein Beitrag zur Frage der Täterschaft in organisatorischen Machtapparaten. Berlin: Duncker \& Humblot. http://dx.doi.org/10.3790/978-3-428-51168-6

Schünemann, B. (1984). Einführung in das strafrechtliche Systemdenken. In B. Schünemann (ed.), Grundfragen des modernen Strafrechtssystems (pp. 1-68). Berlin: N. York. http://dx.doi.org/10.1515/9783110900453.1

Schweikard, D. P. (2010). Verantwortung für kollektives Unterlassen. In: D. Gerber, \& V. Zanetti (eds.), Kollektive Verantwortung und internationale Beziehungen (pp. 94-133). Frankfurt: Suhrkamp.

Van Sliedregt, E. (2012). Individual criminal responsibility in international law. Oxford New York: OUP

Veitch, S. (2007). Law and irresponsibility. On the legitimation of human suffering. Routledge-Cavendish.

Vest, H. (2010). Kollektive Verantwortlichkeit im Völkerstrafrecht? In D. Gerber, \& V. Zanetti (eds.), Kollektive Verantwortung und internationale Beziehungen (pp. 321-346). Frankfurt: Suhrkamp.

Vetlesen, A. J. (2008). Collective evildoing. In R. Jeffery (ed.), Confronting evil in international relations. Ethical responses to problems of moral agency (pp. 61-85). Basingstoke, UK: Palgrave Macmillan.

Werle, G. (2007). Individual criminal responsibility in Article 25 ICC Statute. Journal of International Criminal Justice, 5, 953-975.

Werle, G. (2009). Principles of International Criminal Law. The Hague: TMC Asser Press.

Werle, G., \& Burghardt, B. (2010). Die mittelbare MittäterschaftFortentwicklung deutscher Strafrechtsdogmatik im Völkerstrafrecht? In FS für M. Maiwald (pp. 849-864). Berlin: Duncker \& Humblot.

Zanetti, V. (2010). Völkermord und die kollektive Behandlung von Individuen. In D. Gerber, \& V. Zanetti (eds.), Kollektive Verantwortung und internationale Beziehungen (pp. 372-389). Frankfurt: Suhrkamp.

Al Bashir, Warrant of Arrest for Omar Hassan Ahmed Al Bashir: ICC, Pre-Trial Chamber I, No. ICC-02/05-01/09 (4.3.2009).

http://www.icc-cpi.int/iccdocs/doc/doc639078.pdf

Bemba Gombo, Decision on the Prosecutor's Application for a Warrant 


\section{PAPACHARALAMBOUS}

of Arrest against Jean-Pierre Bemba Gombo: ICC, Pre-Trial Chamber III, No. ICC-01/05-01/08 (10.6.2008).

http://www.iclklamberg.com/Caselaw/CAR/Bemba/PTCIII/ICC-0105-01-08-14-tENG.pdf

Brđanin, Radoslav (Appeal Judgment), ICTY AC (3.4.2007), Case No. IT-99-36-A.

Dissenting opinion of Judge Benjamin Mutanga Itoe in: Prosecutor v. Fofana and Kondewa, SCSL Trial Chamber I, SCSL-04-14-T (2.8.2007).

http://www.sc-sl.org/LinkClick.aspx?fileticket=tjTEj1acqJM\%3d\&ta bid $=104$

Katanga and Ngudjolo Chui, Decision on the confirmation of charges: ICC, Pre-Trial Chamber I, No. ICC-01/04-01/07 (30.9.2008). http://www.icc-cpi.int/iccdocs/doc/doc571253.pdf

Lubanga Dyilo, Decision on the Confirmation of Charges: ICC, Pre-Trial Chamber I, No. ICC-01/04-01/06 (29.1.2007). http://www.icc-cpi.int/iccdocs/doc/doc266175.PDF

Ojdanić, Dragoliub [= Milutinović et al.], ICTY AC (21.5.2003), Decision on Dragoliub Ojdanić's Motion Challenging Jurisdiction-Joint Criminal Enterprise, Case No. IT-99-37-AR 72.

Prosecutor v. Agustinho Atolan alias "Quelo Mauno", East TimorSpecial Panel for Serious Crimes, Dili District Court No. 03/2003 (9.6.2003).

http://wcsc.berkeley.edu/wp-content/uploads/ET-Docs/CE-SPSC $\% 2$ 0Final\%20Decisions/2003/03-2003\%20Agustinho\%20Atolan\%20Ju dgment.pdf

Prosecutor General (Deputy) v. Sisto aka Xisto Barros \& Cesar Mendonca, East Timor-Special Panel for Serious Crimes Dili District Court No. 01/2004 (12.5.2005).

http://www.worldcourts.com/un etta/eng/decisions/2005.05.12 Pros ecutor_v_Barros_Mendonca.pdf

Prosecutor v. Jose Cardoso, East Timor-Special Panel for Serious Crimes, Dili District Court No. 04b/2001 (5.4.2003). http://www.worldcourts.com/un_etta/eng/decisions/2003.04.05_Pros ecutor_v_Cardosol.pdf

Prosecutor v. Damiao Da Costa Nunes, East Timor-Special Panel for Serious Crimes, Dili District Court No. 01/2003 (10.12.2003). http://www.worldcourts.com/un_etta/eng/decisions/2003.12.10_Pros ecutor v da Costa Nunes.pdf

Prosecutor v. Fofana and Kondewa, SCSL Appeals Chamber, SCSL-04-14-A (28.5.2008). http://www1.umn.edu/humanrts/instree/SCSL/SCSL-04-14_files/SC SL-04-14-A-829.htm

Prosecutor v. Kaing Guek Eav alias “Duch”, ECCC Trial Chamber No. 001/18-07-2007/ECCC/TC (26.7.2010).

http://www.worldcourts.com/ecce/eng/decisions/2010.07.26_Co_Pro secutors_v_Kaing_Guek_Eav_alias_Duch1.pdf

Prosecutor v. Joseph Leki, East Timor-Special Panel for Serious Crimes, Dili District Court No. 05/2000 (11.6.2001). http://www.worldcourts.com/un_etta/eng/decisions/2001.06.11 Pros ecutor_v_Leki.pdf

Prosecutor v. Lubanga Dyilo, ICC, Trial Chamber I, ICC-01/04-01/06 (14.3.2012). http://www.icc-cpi.int/iccdocs/doc/doc1379838.pdf

Prosecutor v. Anastacio Martins \& Domingos Goncalves, East TimorSpecial Panel for Serious Crimes, Dili District Court No.11/2001 (13.11.2003).

http://www.worldcourts.com/un_etta/eng/decisions/2003.11.13_Pros ecutor_v_Martins.pdf

Prosecutor General (Deputy) v. Domingos Metan, East Timor-Special Panel for Serious Crimes, Dili District Court No. 4c/2003 (16.11.2004)

http://www.worldcourts.com/un_etta/eng/decisions/2004.11.16_Pros ecutor v Metan.pdf

Prosecutor General (Deputy) v. Francisco Pedro, East Timor-Special Panel for Serious Crimes, Dili District Court No. 01/2001 (14.4.2005).

http://www.worldcourts.com/un_etta/eng/decisions/2005.04.14_Pros ecutor v Pedro.pdf

Prosecutor v. Pereira, East Timor-Special Panel for Serious Crimes, Dili District Court No. 34/2003 (27.4.2005).

http://www.worldcourts.com/un_etta/eng/decisions/2005.04.27_Pros ecutor v Pereira.pdf

Prosecutor v. Salvador Soares, East Timor-Special Panel for Serious Crimes, Dili District Court No. 7a/2002 (9.12.2003).

http://www.worldcourts.com/un_etta/eng/decisions/2003.12.09_Pros ecutor_v_Soares.pdf

Prosecutor v. Sesay, Kallon \& Gbao, SCSL, Trial Chamber I, SCSL-04-15-T (2.3.2009).

http://intlcrimlawdigest.files.wordpress.com/2009/03/20090302scslse saykallongbaotcjudgement.pdf

Prosecutor v. Sesay, Kallon \& Gbao, SCSL, Appeals Chamber, SCSL-04-15-A (26.10.2009).

http://www.refworld.org/docid/4ae9b31c2.html

Prosecutor v. João Sarmento, East Timor-Special Panel for Serious Crimes, Dili District Court No. 18A/2001 (12.8.2003).

http://www.worldcourts.com/un_etta/eng/decisions/2003.08.12_Pros ecutor_v_Sarmento.pdf

Prosecutor v. Milomir Stakić (Trial Chamber Judgment), ICTY TC (31.7.2003), Case No. IT-97-24-T.

Prosecutor v. Milomir Stakić (Appeals Chamber Judgment), ICTY TC (22.3.2006), Case No. IT-97-24-A.

Prosecutor v. Ch. Taylor, SCSL Trial Chamber II, SCSL-03-1-T (26.4.2012) http://www.refworld.org/docid/4f9a4c762.html

Prosecutor v. Mateus Tilman, East Timor-Special Panel for Serious Crimes, Dili District Court No. 08/2000 (24.8.2001).

http://www.worldcourts.com/un_etta/eng/decisions/2001.08.24_Pros ecutor_v Tilman.pdf 